\title{
H1stological Changes In The Uterus And Ovary Of The Albino Rat Following Oral Administration Of $A$-Chlorohydrin
}

\author{
Fouad A.F.Ali*, Ali A.Abdel Rahman* and Ashraf M.Moustafa** \\ *Plant protection Dept, faculty of Agriculture, Al-Azhar Univ; \\ ** Histology Dept., Faculty of Medicine, Al-Azher Univ.
}

\begin{abstract}
The antifertility effects of $a$ - chlorohydrin were re-investigated in female albino rats. FemaIes were treated with a single oral dose (50 mq a.i/Kg. bw) of and six females were sacrificed at intervals of 1,3,7,14 and 21, days from treatment.

The uterine changes were in the form of an increase lumenal folding with areas of metaplasia, some cellular vaculization and increased the collogen deposition in the endometrium. These changes were more noticed in $1^{\mathrm{s} 1}, 3^{\text {rd }}$, and $7^{\text {th }}$ day of the drug intake. The ovarian changes were in the form of decreased number of growing follicles and absence of both Graafian follicles and corpora lutea. It is clear that, treatment of female rats with a chlorohydrin caused reversible uterine and ovarian changes. Uterine changes took longer time to recover compared with that of ovarian changes. These results support the possibility that this drug could be a functional female sterilant as it was known as a male sterilant.
\end{abstract}

\section{Introduction}

After the discovery of the rodenticidal and chemosterilant effects of $a$-chlorohydrin (3-chloro- 1,2- prop anediol, U- 5897, Epiblock $\AA)$.

Against rats (Ericsson, 1969), it was soon recognized that this was unusually interesting functional male sterilant. Males with sexual gonads external to the body cavity, are susceptible to sterility, while, females from all rodent species tested are immune to sterilant property of $a$ chlorohydrien (Meehan \& Hum, 1979; Erjcsson, 1982). Therefore, previous investigations had been focused mainly on the effect of $a$-chlorohydrin on male reproductive system (Jones, 1978; Lobi, 1980, Wagenfeld et al., 1998). The aim of the present work is to re-examine the effect $a$-chlorohydrin against the reproductive system of female rats.

\section{Material And Methods}

A colony of albino rats (Rattus norvegicus albinus) has been started and built up in Plant Protection Dept., Faculty of Agriculture, Al-Azhar University, since 1991 (AH, 1992). Fifty adult female rats of proven fertility were selected for the present study. Their body weights ranged from 195$235 \mathrm{~g}$ - Each female was housed singly in metal cage under conventional conditions $\left(25+_{-}: 3^{\circ} \mathrm{C}\right)$ and maintained on ad libitum pellet diet and water. The first 30 female rats (group I) were treated with a-chlorohydrin, while, the other 20 females (group II) were used as control. 
A sample of formulated $a$ chlorohydrin (35\% W.P) was obtained from Rodent Control Dept., Plant Protection Institute, Dokki, Cairo. Prior to dosing, animals were deprived of food for 15-18hr. overnight but given free access to water. A single oral dose of $50 \mathrm{mg}$ ai $/ \mathrm{kg}$ b.w was used. Solutions of a-chlorohydrin in propylen glycol or of the vehicle alone were administered orally to rats of group I and II, respectively, at $0.1 \mathrm{ml} / 100 \mathrm{~g}$ of rat and immediately given access to food. Six rats from group I and four rats from group II were sacrificed at intervals of $1,3,7,14$ and 21 days from treatment. At each time interval, ovaries and uteri were removed from each animal, fixed in Bouin's fluid, embedded in paraffin wax and sectioned at 6um. Two staining techniques were used. Heamatoxylin and eosin (H. \& E.) was used for possible morphological changes, while mallory trichrome stain (M.T.) for follow up of the changes in distribution and content of collagenous bundles within uterine and ovarian tissues. (Claydon, 1971).

\section{Results}

When female albino rats were treated orally with a single dose of 50 $\mathrm{mg} / \mathrm{kg}$ of $a$-chtorohydrin, none of the rats died or showed any signs of intoxication during the experimentation period.

The histological examination showed that $a$-chlorohyprin affects both the uteri and ovaries of intoxicated female albino rats.

The uterine changes appeared 24 hours post-treatment. The main changes were in the form of an increase of lumenal folding with areas of metaplasia, some cellular vaculization, increased collagen deposition in the endometrium and reduction in the number of endometrial glands (Fig 1$3,4)$. These changes reached maximal severity after 3 and 7 days from the treatment, in which epithelial endom etrial shedding, areas of cellular infilteration and vascularization were very apparent.

After 14 days of the drug intake, these changes were gradually abated, but still an area of metaplasia seen in the endometrium surface-After 21 days,

Fig I : Photomicrographs of sections in the uteri of female albino rats following oral administration $(50 \mathrm{mg}$ / kg) of $a$-chlorohydrin.

Fig. 1 : Section of control uterus showing the normal uterine structure (H.\&E stain X100)

Fig. 2 : Section of control uterus showing the normal distribution of collagen. (Mallory trichme stain X6)

Fig. 3 : Section of treated uterus after 24 hours showing an area of metaplastic changes (arrow) and cellular vaculization. And cell infilteration (H.\&E stain X150)

Fig. 4 : Section of treated uterus after $24 \mathrm{hrs}$ showing increased collagen deposition in the endometrium (Mallory trichrome stain X150)

Figs. 5,6 : Section of treated uterus after 3 weeks showing nearly normal uterus but still lumenal folding and glandular dilatation.

Fig .5 : (H.\&E stain X150)

Fig. 6 : (Mallory trichrome stain X150) 

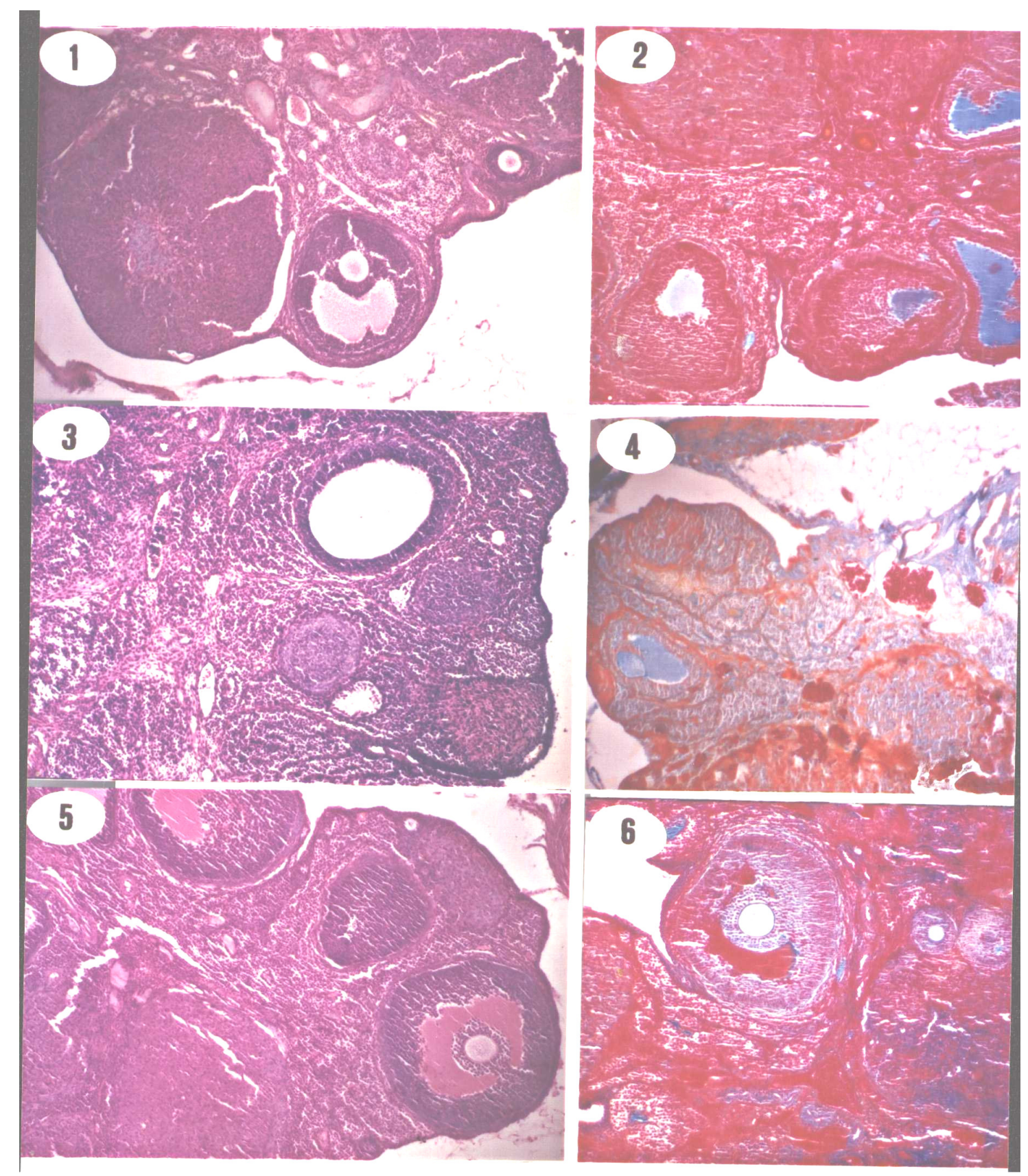

appeared nearly in normal structure, but still an increase in lumenal folding and glandular dilatation (Fig. 1-5 and 6).

The microscopic ovarian changes were also noticed 24 hours posttreatment (Fig. II). The number of growing follicles and corpora lutea as well as the intrafollicular connective tissues were greatly reduced. In addition, no fully mature Graafian follicle was seen. .These ovarian changes reached maximal severity after 3 days, were gradually abated by the end of the first week and were entirely absent after the second week of treatment. At the second and third week of treatment, the distribution of both fibrous and vascular elements as well as the whole ovarian tissues were returned back to normal structure. 
From the above, it is clear that, treatment of female albino rats with a single oral dose of $50 \mathrm{mg} / \mathrm{kg}$ of $a$ chlorohydrin caused reversible uterine and ovarian changes. The uterine changes took longer time to recover compared with that of ovarian changes.

Fig II : Photomicrographs of sections in the ovaries of female albino rats following oral administration $(50 \mathrm{mg} /$ kg) of $a$-chlorohydrin.

Fig.1 : Section of untreated control ovaries showing normal ovarian structure. . (H. \& E. stain X200)

Fig.2 : Section of untreated control ovaries showing normal distribution of ovarian fibrous elements (Mallory trichrome stain X200)

Figs.3,4 : Sections of treated ovaries after 24 hours showing reduction in thnumber of growing follicles and the amount of interfollicular tissue no mature graafian follicle is seen.

Fig.3 : (H. \& E. sta in X200)

Fig.4 : (Mallory trichrome stain X200) Figs. 5,6 : Sections of treated ovaries after 3 weeks showing complete recovery to normal ovarian structure.

Fig.5 :(H.\&E stain X200)

Fig.6 : (Mallory trichrome stain X200)
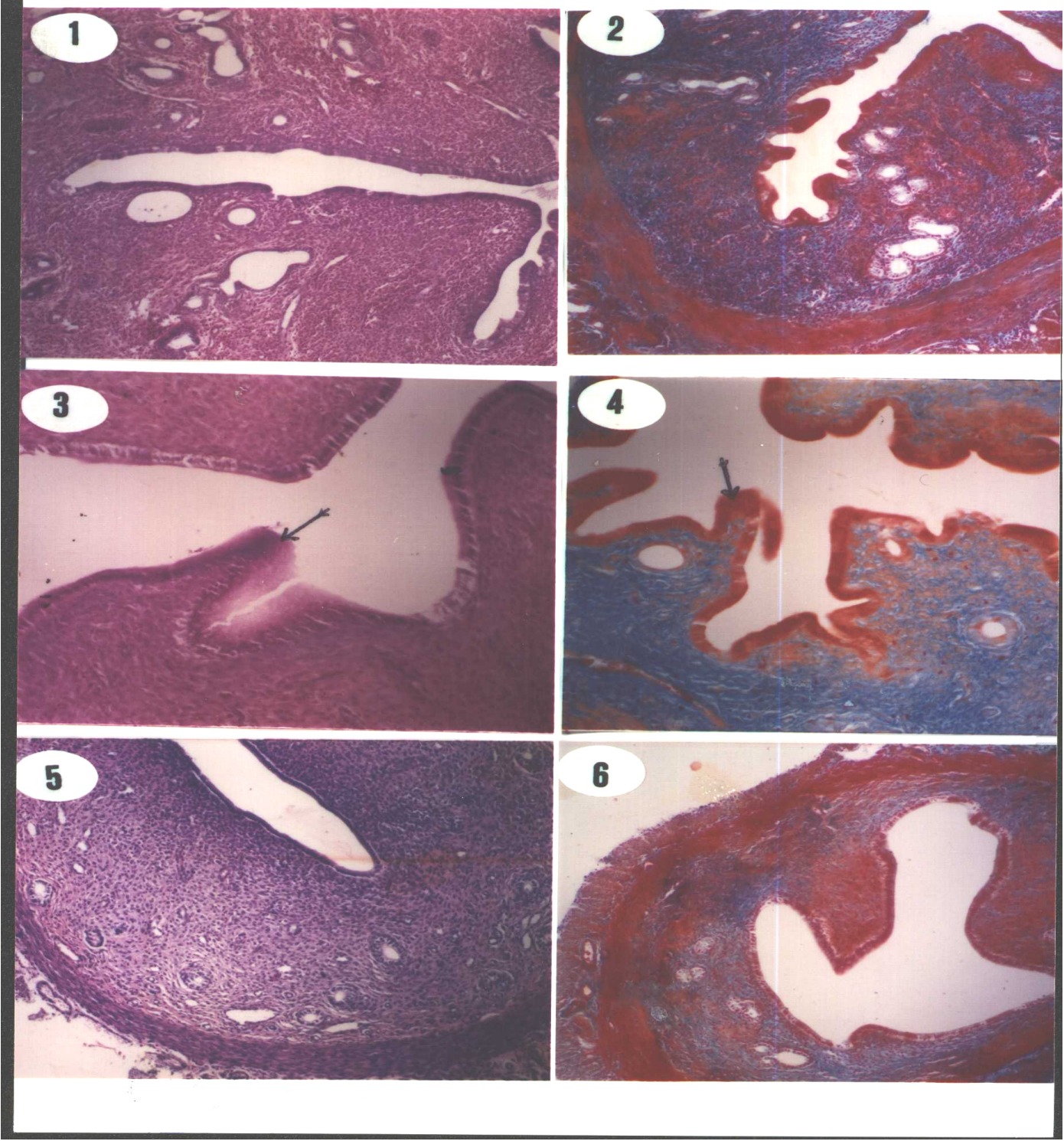


\section{Discussion}

The dose of $50 \mathrm{mg} / \mathrm{kg}$ of $a$ chlorohydrin was selected because previous workers (Ericsson, 1970; Reijonen et al ;1975) showed that a single oral dose around $45 \mathrm{mg} / \mathrm{kg}$ induced permanent sterility in male rats without any lethal effects. Moreover, Saint \& Parshad (1988) reported that of the 15 species or strains of rodent studied, no mortality was observed at any dose less than $100 \mathrm{mg} / \mathrm{kg}$ of achlorohydrin except for the Indian mole rat which seemed to be the most susceptible species to the toxic and antifertility effects of $a$-chlorohydrin.

The histologica! examination showed that $a$-chlorohydrin caused many structural alterations of both the uteri and ovaries of treated rats. This finding is in contradictory with those obtained previously (Meehan \& Hum, 1979; Ericsson, 1982). For example, Meehan \& Hum (1979) found that when female Wistar rats fed on baits containing $a$-chlorohydrin at concent rations of $0.25,0.5,1.0$ and $2.0 \%$ for four days, no gross morphological changes were noticed in female reproductive system and microscopic examination indicated normal ovaries.

The uterine changes observed in the present study indicate that the irritant effect of $a$-chlorohydrin greatly affects the uterine wall making it unsuitable for ovum implantation and so depress the fertility rate in treated female rats. This interpretation indorses the finding of Rahmaniah \& Sutasurya (1999) who found that pregnant Wistar rats administered $a$-chlorohydrin by gavage at 75 and $90 \mathrm{mg} / \mathrm{kg}$ during the pre-implantation period $\left(1^{\text {st }}\right.$ day of gestation) caused significant decrease of implantation number and increased the gestation loss as well as the post implantation mortality compared to the control rats. Also,this irritant effect of $a$-chlorohydrin may attract the inflammatory cells causing cellular infiltration in the uterus (Walter and Istrael, 1974).

The interpretation of cellular vaculization has been subjected to many speculations. Rouiller (1956) looked at these vacuoles as a defence mechanism responsible for collecting the injurious elements and preventing them from interfering with the biological activation of the cells. Grasso et al. (1974) reported that such cytoplasmic vacuolization might be a consequence of destruction of lysosomal particles. EL-Banhawy et al (1993) believed that cytoplasmic vacuolization is mainly a consequence of a considerable disturb ance in fat metabolism occurring under such pathological cases.

The ovarian changes were observed after $24 \mathrm{hr}$ and 3 days from the drug intake. These changes were in the form of decrease the number of growing follicles and corpora lutea and the absent of mature graafian follicle. Such changes are good indication that $a$ chlorohydrin affects the process of oogenesis in the ovary of treated rats.

Previous reports pointed out that $a$-chlorohydrin has a direct effect on the endocrine system of treated rats. Dixit et al. (1974) found that $a$-chlorohydrin induced transient changes resembling those of castration in the anterior pituitary, while, Morris \& Jackson (1978) postulated that $a$-chlorohydrin caused changes of the levels of serum gonadotropins. Thus, the possibility exists that such pituitary hormonal changes may be responsible for uterine and ovarian structural alterations, which in turn, inhibits any chance of conception.

The point to be made is, although none of the experimental animals died 
or showed any signs of intoxication, the damage of uterine and ovarian tissues was evident. Therefore, these results support the possibility that $a$ chlorohydrin could be a functional female sterilant as it was known as a male sterilant.

\section{References}

1. AH, F.A.F (1992): Potentiation of anticoagulant effect of coumachlor rodenticide in adult albino rats. AlAzhar J. ofAgric. Res. 15: 257-268.

2. Claydon, E.G. (1971) : Practical section, cutting and staining. $5^{\text {th }} \mathrm{Ed}$. Churchill Living stone, London.

3. Dixit.V.P; Lohiya, N.K ; Jain, H.C. (1974): Effects of a-chlorohydrin and gonadectomy on the adenohypophysial cells of male rats and gerbils. J. Reprod- Fertil- 38 : 185.

4. El-Banhawy, M.A; Sanad, S.M.; Sakr, S.A; EL-Etaimy I-A and Mahran, H. A. (1993) : Histopathological study on the effect of the anticoagulant rodent -icid brodifacoum on the liver of rat. J.Egypt. Ger. Soc. Zool. 12: 185-227.

5. Ericsson, R. J. (1969): A posttesticular antifertibity drug. J. Reprod. Fertil. 18:156.

6. Ericsson, R. J. (1970): Male antifer tility compounds ; U-5897 as a rat chemosterilant. J. Reprod. Fertil. 22 : 213.

7. Ericsson, R. J. (1982):AlphachIorohydrin (Epibloc $\left.{ }^{\circledR}\right)$, A toxicant sterilant as alternative in rodent control. Proc. Tenth Vert. Pest conference (Marsh, Ed.) Univ.of California, Davis.

8. Grasso, P.; Wright, M.G.; Gangolli, S.D and Hendy, R. (1974): liver response tests. IX. Cytological changes in the enlarged but histologically normal rat liver. Fd. Cosmet. Toxicol$12: 341$.

9. Johnes, A. R (1978) ; Minireview - the antifertibity actions of a-chlorohydrin in the male. Life Sci. $23: 1625$ 1646.

10. Lobi, T. J (1980) : $a$-chlorohydrin; review of a model post-testicular antifertibity agent, pp 109-122 in G.R. Cunningham;W.B. Schill; E.S.E Hafez (Eds), Regulation of male fertibity, Martinus Nijhoff Publ. Hague, Boston, London.

11. Meeham, A.P and Hum M.C (1979) : The rodenticidal and. chemosterilant effect ofU-5897 (alphachlorohydrin) against rats. Inter. Pest control. Marsh / April : 39-41.

12. Morris, I. D and Jackson, C.M (1978) : Gonadotropin changes in male rats following a sterilizing dose of achlorohydrin. Int. J. androl. $1: 86$.

13. Rahmaniah and Sutasurya, L.A (1999), The effects of alpha chlorohydrin on the gestation of the Wistar rat [Rattus norvegicus). Biotropia, $12: 25-30$.

14. Reijonen, K; Konnano, M; Ericsson, R.T (1975) studies on the rat epididymal blood vessels following alpha chlorohydrin administration Biol. Reprod. 12:483 $-490$.

15. Rouiller, C. (1956) : The liver. Experimental toxic injury of the liver. Academic press. New York. pp. 335 476.

16. Saini, M.S. and Parshad, V. R (1988). Laboratory evaluation of a toxicantsterilant,alpha-chlorohydrin, for the control of Indian mole rat Bandicata bengalensis. Ann. Appl. Biol. 113 : 307-312.

17. Wagenfeld, A; Yeung, C.H; Strupat, K; copper, T.G (1999): Shedding of a rat epididymal sperm protein associated with infertility induced by ornidazole and a-chlorohydrin. Biol. Reprod. 58 ; 1257-1265.

18. Walt Walter, J. B and Israel, M.S. (1974): General pathology. $4^{\text {th }}$ edn 


\section{التغير ات الهستولوجية في رحم ومبيض الجرذ الأبيض تحت تأثير عقار الفاكلوروهيدرين}

فؤاد احمد فهمي ـ *علي عبد اللاة عبد الرحمن - **اشرف محمود مصطقي

*قسم حماية النبات كلية الزر اعةٌ و ** قسم الهستولوجي

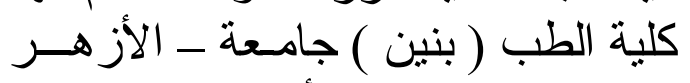

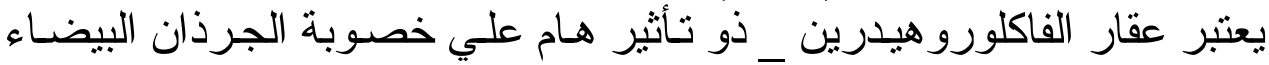

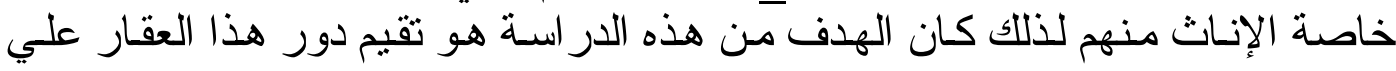

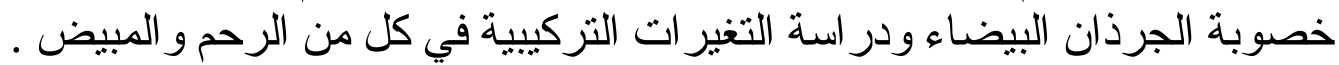

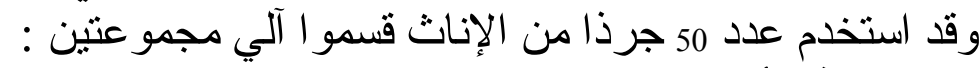

المجموعة الأولي : الماند

اشتملت علي 30 جرذا تم إعطائهم عن طريق الفم جرعة 50 مليجر ام لكل كيلو من

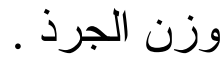

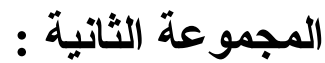

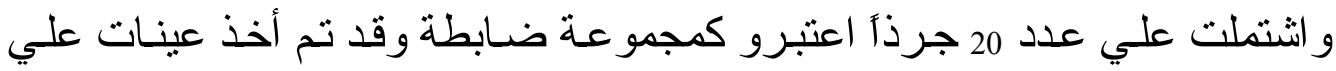

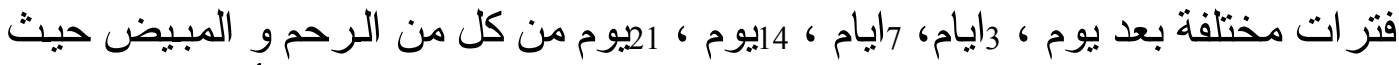

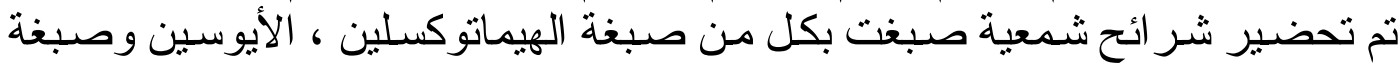

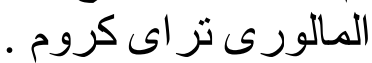
وقد دلت النتائج علي مدي تأثنير كل من الرحم و المبيض تحت تأنثير العقار وذلك التك

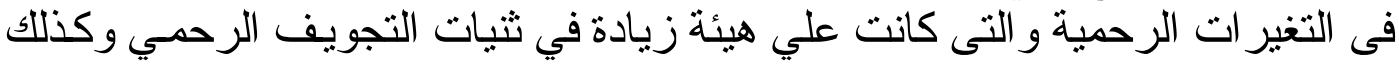

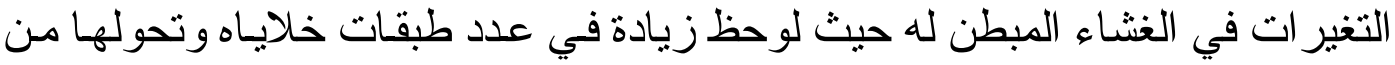

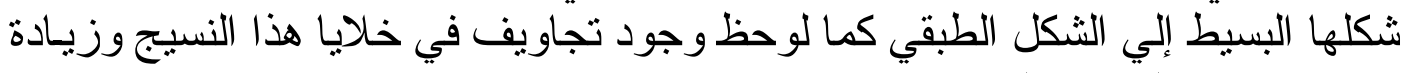

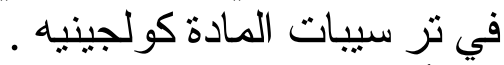

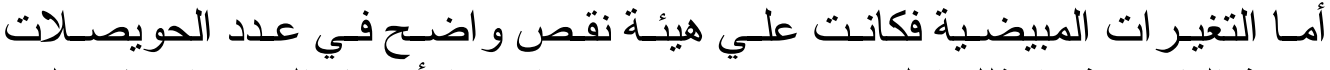

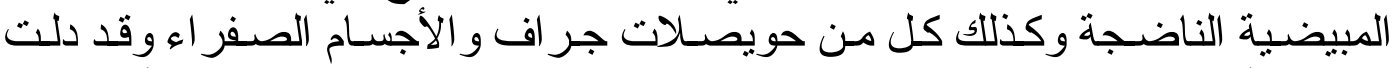

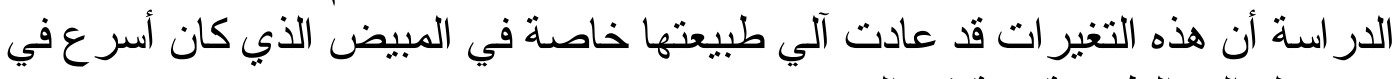

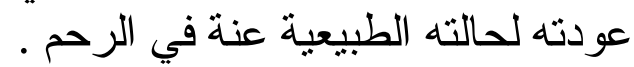

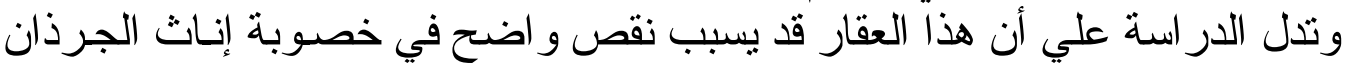

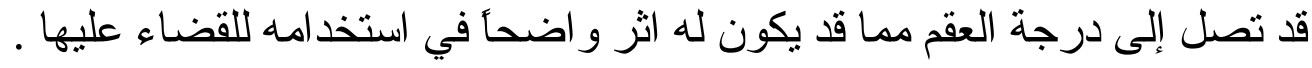

